\title{
Implementation App Google Classroom In Online Learning IPA The Pandemic Covid-19
}

\author{
Nurkhilal $^{1)}$, Irham Huspa K. Siregar ${ }^{2)}$, Kurnia Putra*3) \\ 1,2,3) Fakultas Keguruan dan Ilmu Pendidikan, Universitas Islam Labuhan Batu, Rantauprapat
}

*Coresponding Author

Email : kurniaputra.mpd@gmail.com

\begin{abstract}
The objectives to be achieved in this research are: (1) to know the implementation of google apps classroom; (2) to determine the creativity of teachers in implementing google apps classroom; (3) the constraints experienced by teachers in implementing google apps classroom; and (4) the efforts done by the teacher to overcome the obstacles in implementing app google classroom. The research method uses a qualitative approach with descriptive method. Data sources in this study include primary sources and secondary sources. The informant in this research is the head of the school, waka curriculum, SCIENCE teacher, and eight students in SMK negeri 1 Rantau Utara. Data collection techniques used were interviews and documentation. The technique of data analysis consists of data reduction, data presentation, and conclusion. While checking the validity of data using triangulation of sources. The research results revealed that: (1) the implementation of google apps classroom shows three teachers using the app matches the policy of the head of the school; (2) the creativity of teachers in implementing google apps classroom of the three teachers vary in their creativity; (3) the Constraints experienced by teachers in implementing the application google classroom is influenced by the lack of communication to students, and signal; and (4) the Efforts done by the teacher to overcome the obstacles in implementing google apps classroom with communication to students, parents, homeroom, and others that play a role in the process of learning online.
\end{abstract}

Keywords: The Implementation Of Learning, Google Classroom

\section{INTRODUCTION}

In the course of the policy of the independent study, which was conceived by the Minister of Education of the Republic of Indonesia Nadiem Makarim, Indonesia is currently being ravaged by the outbreak of coronavirus disease (Covid-19). The state of the outside of the prediction in the form of an outbreak of the disease Covid-19 has brought urgent changes to various sectors and even the world. The development of the virus quickly spread around the world every day data in the world to preach the increasing scope and impact of Covid-19.

Indonesia has entered the national emergency with a mortality rate of due to the spread of the virus continued to rise since the announcement of the first times there are people who are positively affected by the virus Covid-19 in early March 2020. It affects the changes and update the policy to be applied. The new policy also occurs in the world of education is changing the learning that should come to class or a building or campus to be quite at home only. The advice from the Government to stay at home and physical distancing and social distancing must be followed to change the learning mode face-to-face learning to be online. 
In practice, $50 \%$ of teachers still have to go to school to guard or picket. In school the teacher on duty is to monitor the development of government policy, to overcome the existing problems and ensure the condition of the school safe. $60 \%$ of teachers actually a holiday full in the sense of working from home, not in school at all. But even though the students are learning at home, learning activities to keep running and transitioned to online learning or learning in the network.

Online learning is a program of the implementation class in the network to reach out to the target group are massive and extensive. Through the network, learning can be organized and participated in free and paid (Bilfaqih and Riza, 2015). Although now learning in the midst of the Pandemic Covid-19 redirected to online, stay with the role of the teacher as an educator to be a critical success factor in achieving the goal of education in the future. The implementation of a tool or media, or app which is applied from each school, the teacher must have high creativity to the understanding of the concept up to the students. Teachers in the context of education has a very large role and strategic. With creative learning will not cause a sense of restlessness, anxiety and fear to the students so that it will create creative learning and fun in every meeting. Based on the results of the interview on April 15, 2021 with the Head of School, Deputy Head of the Curriculum and some of the teachers, especially teachers teaching science in SMK negeri 1 Rantau Utara, when the initial announcement of learning at home and learning the switch to online learning, the first day of the direct Head of the School with the curriculum team to determine that the application google classroom to be used as a solution in online learning amid the pandemic Covid-19. The initial preparation is done by equip all teachers in SMK negeri 1 Rantau Utara first, because not all teachers can take advantage of the app google classroom. According to the Judge (2016) application of Google Classroom is a use application that allows classrooms in the virtual world. In addition, google classroom can be a means of distribution of tasks, submit assignments, and even rate the tasks that were collected.

This application can help facilitate teachers and students in carrying out the learning process with more depth. This is due to both students and teachers can collect assignments, distribute assignments, grade assignments at home or anywhere without being tied to a time limit or hours of lessons. App use google classroom is made as a medium of learning online during the Pandemic Covid-19, especially in SMK negeri 1 Rantau Utara.

In the implementation, utilization facilities app google classroom as a media in online learning science, learning is expected to keep running in accordance with the achievement of the indicators of learning. Although online learning can be done with google apps classroom, but every teacher has their own way of teaching and managing the application so that it not only as a form of liaison to students, but how can teachers hang of learning materials though not directly face to face. Because so far, the Head of the School support with the use of google apps classroom and the rest of the app management google classrom submitted to the teacher of each subject.

\section{RESEARCH METHODS}

\section{Research Design}

In this study, using a variety of methods in data collection. The research method used in this research is a qualitative approach of descriptive type. As said by Richie in Moelong (2012) that qualitative research is an attempt to present the social world and her perspective on the world in terms of concepts, behavior, perception, and issues about the man who researched, so it is expected that the data obtained is data that is original and intact. Qualitative methodology as a 
research procedure that produces descriptive data in the form of words written or spoken of the people and observed behavior in order to get the data that really fit the facts from the place of study and sources.

Researchers in preparing the research instrument using the theory of Miles and Huberman in Sugiyono (2016) where the instrument or tool of the research is the researcher itself, which serves to set the focus of the study, selecting informants as a source of data, collecting data, assessing data quality, data analysis, interpret the data and make conclusions on their findings so obtained a valid instrument. In selecting the respondents, the researchers used a technique of the interview is structured, while the technique of data collection the researcher used interview and documentation. In the validity of the data, the researcher uses triangulation of sources that compare the results of the interview between primary sources with secondary sources so that in the end obtained a final conclusion and valid.

\section{The place and Time of Research}

The purpose of this study is to get an overview and information that is clear, complete, and allows for researchers to conduct interviews and documentation. Therefore, the researchers set the location of research is in SMK negeri 1 Rantau Utara, which is located in Jalan Jend. Ahmad Yani No. 32, Kartini, Rantau Selatan Labuhan Batu, Sumatera Utara 21411. The reason the researchers doing research in the school because no one has ever conducted a similar study in the area. The other reason was the interest of researchers to the process of online learning IPA using google apps classroom the Pandemic of Covid-19 and want to know the creativity of teaching SCIENCE teacher in implementing google apps classroom at learning online IPA the Pandemic of Covid-19 in SMK negeri 1 Rantau Utara. This research was carried out starting from the planning of the research, implementation research, to manufacture a research report. This research was conducted at the end of July to August 2021.

\section{Population and Sample}

In this study, which become the main data source is the Head of the School, Waka curriculum, three of the five Science teacher who has an understanding and implementing online learning Science by using the app google classroom in SMK negeri 1 Rantau Utara to dig data on how the implementation of google apps classroom in online learning IPA the Pandemic Covid-19, how the creativity of teaching Science teacher in implementing google apps classroom in online learning IPA the Pandemic Covid-19, how the constraints of the time of execution of, as well as how the efforts made in overcoming these obstacles.

The sample is the subject of a real or part of the population into research material. In this research, secondary data sources were students with a sample of eight students. each is a four12th grade students, two students of class 11, and two students in grade 10 with the criteria of the students were really students from the Science teacher respondents and understand about google classroom.

\section{Research Instruments}

According to Sugiyono (2016) in qualitative research, which became the instrument or tool of the research is the researcher itself, which serves to set the focus of the study, selecting 
informants as a source of data, collecting data, assessing data quality, data analysis, interpret the data and make conclusions on their findings. The research Instrument is a tool at the time of the study using the method. One of the purpose of the instrument is to acquire the data and complete information regarding the matters to be examined in this study. Instruments used in this research are interview guidelines given to the head of school, deputy head of the school, teachers and students, as well as documentation guidelines ranging from documentation of the school's identity, photo research activities, the time of the interview.

\section{Data Analysis Techniques}

Data analysis is the process of systematically searching and preparing data obtained from interviews, field notes, and other materials, so it can be easily understood, and its findings can inform other people. In this study, the data collected will be processed so that the obtained information is further used as the material description.

According to Sugiyono (2016) in qualitative research, which became the instrument or tool of the research is the researcher itself, which serves to set the focus of the study, selecting informants as a source of data, collecting data, assessing data quality, data analysis, interpret the data and make conclusions on their findings. The research Instrument is a tool at the time of the study using the method. One of the purpose of the instrument is to acquire the data and complete information regarding the matters to be examined in this study. Instruments used in this research are interview guidelines given to the head of school, deputy head of the school, teachers and students, as well as documentation guidelines ranging from documentation of the school's identity, photo research activities, the time of the interview.

\section{Data Analysis Techniques}

Data analysis is the process of systematically searching and preparing data obtained from interviews, field notes, and other materials, so it can be easily understood, and its findings can inform other people. In this study, the data collected will be processed so that the obtained information is further used as the material description.

\section{RESULTS AND DISCUSSION}

\section{Analysis Of The Implementation Of Google Apps Classroom}

Implementation is the implementation of actions by individuals, officials, government agencies, and private groups with the aim of reaching the goals that have been outlined in a particular decision. In the journal of the Implementation of the Utilization of Google Classroom in the Process of Online Learning in the Era of 4.0 concluded that with the implementation of google apps classroom in an online learning in school, have an impact on the involvement of educators and students actively in the learning process online such. This method can simplify the process of learning where students are not limited to the classroom and books are available. Based on the findings of research studies that have been described, the use of the app google classroom in online learning IPA the Pandemic of Covid-19 in SMK negeri 1 Rantau Utara, is the policy of the school and the curriculum team by reason of user friendly, inexpensive, easily accessible, and teachers have no difficulty in managing, as well as 
effective and efficient. However, teachers may also add other applications in support of online learning IPA, such as whatsapp to communicate with students and guardians of students and also the youtube app as a form of teacher creativity in the add media pembelajaran. With the application, a science teacher more easily greet students per class, providing materials, assignments, or quizzes as well as can include photos or video, so the task is targeted to the students.

From the findings, the researcher can analyze that the process of implementation of online learning IPA the Pandemic of Covid-19 in SMK negeri 1 Rantau Utara, run in accordance with the school policy as a form of independent learning that the learning is done online. The process of starting with his commanding students to download the app google classroom on a laptop or gadget each as a trial later implemented learning online. Further explanation to the implementation of the submitted to the class teacher each how grooves using the app to be used in the process of learning online mathematics.

The selection and the decision to use the application google classroom to be an alternative way for the process of online learning to keep it running effectively and efficiently even in the Pendemi Covid-19. The head of School and Deputy Head of the Curriculum also always conduct an evaluation that is conducted each week in order to know the development process of online learning in SMK negeri 1 Rantau Utara. Although the process of online learning IPA using the app google classroom has been running more or less four months, but the enthusiasm of the teachers and students still performed with the passion and motivation to always learn. This is in accordance with the answers of a sample of eight students who were students in SMK negeri 1 Rantau Utara who have competent and understand the application of google classroom.

\section{The creativity of Teachers in Implementing Google Apps Classroom}

Creativity is According to Rusman (2011) said that the creative teacher can be described through nine skills teaching, namely: (1) Skills open the lesson; (2) asking Skills; (3) providing reinforcement; (4) Skills hold variations; (5) Skills explained (Explaining Skills); (6) Skills to guide small group discussion; (7) classroom management Skills; (8) learning Skills of individuals; and (9) the Skill of closing the lesson.

While the creativity of teaching SCIENCE teacher in implementing google apps classroom at learning online IPA the Pandemic of Covid-19 in SMK negeri 1 Rantau Utara is as follows:

\section{a. The creativity of Preparation on the Online Learning IPA}

On the implementation of teaching and learning, teachers will do the preparation so that the learning can be effective and efficient. Teachers can improvising all forms of media and material for support quality learning. It is also possible if all the preparation is added even though the learning is done online or not face-to-face.

Preparation a SCIENCE teacher in SMK negeri 1 Rantau Utara in online learning IPA, first is to prepare the material with the search for material-material from the book good books and electronic books. In addition, teachers looking for material on the internet that are relevant to the material where the learning is online IPA takes place. Aside from books and the internet, teachers are also looking for the video from youtube so that students can better understand the material should still be considered abstract. Do not forget, of each teacher at any level in the online learning also set up the example problems and questions that can be said easily in small amounts, so that students will better understand the material and can train students in evaluating the results of learning with the workmanship of the questions given by the teacher. Both material and of the problems given in accordance with what has been listed. 
b. The creativity of the Implementation of the Online Learning IPA

The implementation of online learning IPA conducted a Science teacher in SMK negeri 1 Rantau Utara after the preparation, the next teachers to share learning materials in the form of soft file in the form .pdf or word, photo, or video on google apps classroom and group whatssapp class. Also attached the example problems useful add students ' understanding of the material that has been shared by the teacher so that students more easily understand.

Teachers are also always monitor the students with communication using via whatsapp for online learning SCIENCE progresses. If the student does not have a quota to open the app google classroom, with quick teacher also share task information through the whatsapp group. With the communication through group or private messages to students, allowing the teacher to monitor the students related to the extent in understanding the material and allow teachers to provide the appeal for the students to complete the task that must be collected.

\section{c. Creativity Assessment or Evaluation of Students in Online Learning IPA}

Assessment of student learning outcomes for online learning IPA the Pandemic Covid-19, using the app google classroom, google form, or via whatsapp. For the application of google classroom teacher assessment with quizzes, multiple choice questions and the description is continued with the students ' answers will automatically appear in the google form so as to facilitate teachers in analyzing student grades. Not infrequently of the students have to really being chased through a private message so that task because it will enter into judgment but the teacher also give an extension of time if there are students who really difficulty for example does not have a quota for the task.

\section{d. Creativity Understanding of the Concept in Online Learning IPA}

In online learning the IPA of the material studied there are some that are still not wellunderstood give understanding of the concept to the students a more in-depth how to give notes and open the opportunity to the student for consultation using the whatsapp application. Note the material given in accordance with the creativity of the teacher, for example by giving the example image, how to groove about the settlement, and others. If in the group of students still can not understand the material, the teacher gives the students the chance to ask you directly through a private message so that the material referred to by the teacher in line with the understanding that students learn.

\section{e. Creativity Cultivate Enthusiastic Students in Online Learning IPA}

As for that be teachers, motivating students to always be working on the task even though the learning switch to online, always communicate as well as to give sense to the students that the spirit of learning should still be run in any situation and any condition. Not to forget the teachers always greet in a google apps classroom and whatsapp groups so that students feel the proximity of students to teachers is not rigid with the learning even have to learn from home in the middle of the Pandemic covid-19. Not only that, the teachers also say hello to group the society of guardians of students to monitor and facilitate communication between teachers and guardians of the students related to the development of learning in the home. 


\section{CONCLUSION}

Based on the results of qualitative research with the techniques of observation, interview and documentation conducted in SMKN 1 Rantau Utara, about the Implementation of google apps classroom as the following:

1. The implementation of google apps classroom in online learning IPA the Pandemic of Covid-19 in SMK negeri 1 Rantau Utara school Year 2019/2020 show that a Science teacher using the application in accordance with the policy of the head of the school as a form of independent learning in the middle of a Pandemic that is with held the process of learning online. The process of implementation of the use of this application is very useful in online learning IPA, because it gives ease in the implementation of learning is still based on the Implementation Plan of Learning. Preparations are underway to set up the material which is ripe, the implementation by providing material that is easily understood, as well as the assessment of students is carried out from the google app classroomi and the form of the assignment of the other.

2. Creativity teaching Science teacher in implementing google apps classroom at learning online IPA the Pandemic of Covid-19 in SMK negeri 1 Rantau Utara vary in developing apps google classroom. SCIENCE teacher also uses the google form, youtube, whatsapp for assignments and communication with students. In addition, the teachers add a link, photo, video share to all of the students to the hang of the concept the material so that the students easy to learn and do the task given.

3. Constraints experienced Science teacher in implementing google apps classroom at learning online IPA the Pandemic of Covid-19 in SMK negeri 1 Rantau Utara in general is the lack of communication with students in online learning that is influenced by factors signal the place of residence of the students, the absence of hp students, quota, and the tedium of the students to the tasks that accumulate to be done. In addition, working hours that accrue to do in the house related to always be online to monitor the progress of students during the learning at home.

4. The efforts made SCIENCE teacher to overcome the obstacles in implementing google apps classroom at learning online IPA the Pandemic of Covid-19 in SMK negeri 1 Rantau Utara is to ask the teacher, who can already use google apps classroom, always communicate to students and parents, homeroom, BK teachers regarding the development of online learning at home while controlling students to keep working on the task with a good and disciplined, even if learning redirected to online. 


\section{REFERENCES}

Bilfaqih, Yusuf dan M. Nur Qomarudin. 2015. Esensi Pengembangan Pembelajaran Daring (Panduan Berstandar Pengembangan Pembelajaran Daring untuk Pendidikan dan Pelatihan). Yogyakarta: Depublish Publisher.

Hakim, Abdul Barir. 2016. Efektivitas Penggunaan E-Learning Moodle, Google Classroom dan Edmodo. Jurnal: I-Statement. Vol. 02 No.1.

Moleong, L.J. 2012. Metodologi Penelitian Kualitatif. Bandung: PT Remaja Rosdakarya.

Sugiyono. 2016. Statistika untuk Penelitian. Bandung: Alfabeta.

Rusman. 2011. Model-model pembelajaran-Mengembangkan Profesionalisme Guru. Cetakan keempat. Jakarta: PT Rajagrafindo Persada 